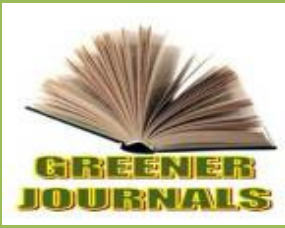

\title{
Assessing Fishing activity, Fish Production and demand outlook in Ilu Abba Bora Zone, Oromia Regional State, South West Ethiopia
}

\section{Tujuba Ayele Tesso ${ }^{1 *}$, Simagegnew Melaku², Tsegaye Dobamo ${ }^{3}$}

\author{
1, 2, ${ }^{3}$ Department of Biology, Mettu University, P.O.Box 318, Mettu Ethiopia
}

\section{ARTICLE INFO}

Article No.: 120316208

DOI: 10.15580/GJAS.2017.1.120316208

Submitted: 03/12/2016

Accepted: $15 / 12 / 2016$

Published: 30/01/2017

${ }^{\star}$ Corresponding Author

Tujuba Ayele Tesso

E-mail: tuj2001@gmail.com

Keywords:

fishing activity, fish production, Ilu Aba Bora, Preferred fish species
The study was aimed to assess fishing activity, Fish production and demand outlook in Ilu Abba Bora Zone, Oromia Regional State, South West Ethiopia to generate base-line data that would help in the proper and sustainable utilization of fishery resources. Different reports, field assessment, structured and semistructured questionnaires and observation were employed as a means of data collection techniques. Five districts (Mettu, Yayo, Bilo Nopa, Bure and Sale Nono) were selected using purposive sampling technique. From each district, fishermen and households along and nearer to riverine water bodies were selected purposively. The fishing activities of the area are on subsistence basis by parttime fishermen for family consumption and sale on small scale during dry season. The fishing gears commonly used are hooks of different sizes, traps (fish basket) locally made and rarely gillnet. Birbira (Milletia ferruginea) is also used by fishermen in Sale Nono district. Though the severity of the constraints varies from one district to the other, the main fish production constraints in the area are low demand for fish, lack of awareness, lack of facilities, low profit, and distance from market place. The fish demand and supply in the study area is unbalanced. Fresh whole fish, gutted and dried fish are mostly preferred fish products. Labeobarbus intermedius, Labeobarbus nedgia, Bagrus docmak and, Oreochromis niloticus are the fish species preferred by consumers in the study area. Awareness creation and promotion of local fish farming is important to integrate fish in their diet to scale up fish demand and supply in the zone. 


\section{INTRODUCTION}

The world's fisheries are under more pressure than ever before. From 1950 to 1990, there was a fivefold increase in the world annual fish catch. The average yearly per person fish consumption in the industrialized world (59 pounds) is three times that of people in the developing world (20 pounds). Fish demand remains high: An additional 15.5 million tons of fish will be required just to maintain current rates of fish consumption. Today, 70 percent of the planet's marine stocks are fully exploited or overexploited (FAO, 2002). The number of people fishing and practicing aquaculture worldwide has doubled since 1970. More than 21 million people are fulltime fishers, and 200 million depend on fishing for their livelihood. Asia contains the vast majority of the world's fishers. In the early 1950s, developed countries took 80 percent of the world's fish catch. Today, they take only 36 percent of the catch, while developing countries take 64 percent (FAO, 2002). Globally, fish provides more than 1.5 billion people with almost 20 percent of their average per capita intake of animal protein, and 3.0 billion people with at least 15 percent of such protein. In 2007, the average annual per capita apparent fish supply in developing countries was $15.1 \mathrm{~kg}$, and $14.4 \mathrm{~kg}$ in low-income food-deficit countries (LIFDCs). In LIFDCs, which have a relatively low consumption of animal protein, the contribution of fish to total animal protein intake was significant at 20.1 percent, and is probably higher than that indicated by official statistics in view of the under - recorded contribution of small-scale and subsistence fisheries. China remains by far the largest fish-producing country, with production of 47.5 million tons in 2008 (FAO, 2010).

In Sub-Saharan Africa, fish is an important food for over 400 million people, contributing essential proteins, minerals and micronutrients to their diets. Paradoxically, despite the high dependence on fish as a source of animal protein, fish consumption in subSaharan Africa is lowest in the world. The continent is projected to need an additional 1.6 million tons of fish a year by 2015 just to maintain current consumption. This demand will increase by a further 2.6 million tons a year by 2030 . Most wild capture fisheries, however, have reached their production limit or are over-fished. The rapid increases in fish supply required over the next decades will only be possible, therefore, if these fisheries are sustained and improved, while simultaneously developing fish farming (World Fish center, 2009).

Ethiopia is endowed with inland waters for fish production as a cheap source of animal protein. It has a number of lakes and rivers with substantial quantity of fish stocks. The total area of the lakes and reservoirs stands at about 7000 to $8000 \mathrm{~km}^{2}$ and the important rivers stretch over $7000 \mathrm{~km}$ in the country (Mebrat, 1993). In addition, minor water bodies such as crater lakes and reservoirs make up about $400 \mathrm{~km}^{2}$ (Tesfaye Wudneh, 1998). Most of the lakes are located in the
Ethiopian Rift Valley depression, which is part of the Great East African Rift Valley system. However, Lake Tana, the largest lake in the country and the source of the Blue Nile River, is located in the northwest plateau outside the Rift Valley. These lakes and rivers are stocked with various species of fish. The potential yield of fish is estimated to be between 30,000 tones and 40,000 t/year for the main water bodies and about 25,000 tones/year from Baro River alone and a large potential from other rivers (FAO, 1995). According to Tesfaye Wudneh (1998) the exploitation of the different water bodies of the country is very uneven. For example, those located near the capital, Addis Ababa, and having good road connection, like Lake Zeway and Lake Awassa, have been heavily exploited to the extent of overfishing. Lake Tana, which is located $500 \mathrm{~km}$ from Addis Ababa, is amongst the least exploited lakes, in spite of its size of $3200 \mathrm{~km}^{2}$ and fish resource. Hence, for most water bodies, the production estimate is far below the estimated potential yield. In 1998, the total production mainly from the Rift Valley lakes is estimated to be about 14,000 tons, (LFDP, 1998) less than $50 \%$ of the estimated potential. There are several reasons attributed to the low production among which the lake of fishing tradition and low fish consumption habit of most people is frequently quoted. Ethiopia has only inland freshwater capture fisheries. It has no significant aquaculture development. The inland capture fishery comprises: Rift Valley lakes (for example, lakes Chamo, Abaya and Ziway and the northern part of Lake Turkana) and Lake Tana, which although shallow, is the largest lake in Ethiopia; rivers; and small water bodies (reservoirs, natural ponds). There is fishing on all these water bodies, but commercial production (i.e. serving markets other than the local communities) is concentrated on the five lakes, with Chamo, Ziway and Tana particularly dominant.

\subsection{Fish production and marketing Challenges in Ethiopia}

Fish production and marketing challenges in Ethiopia is due to inaccessibility of some the water bodies such as rivers and lack of infrastructure, and facilities. In fish production areas, fish consumption patterns reflect the local availability of fish (with some notable exceptions, such as catfish in some areas). Fish Production and Marketing Enterprise (FPME) retail indicated that the range of fish available has increased over the last twenty years, exclusively of Nile perch and tilapia (Gordon et al., 2007). Outside of the production areas, where much of the local trade is in fresh whole fish, there is a relatively strong preference for fillets and most frozen fishes are traded as fillets. Barbus is the exception and is sold whole, gutted and skinned. There is negligible use of ice (as indicated by traders and observed with only some trucks using ice to limit thawing of frozen fish being transported overnight from production areas to Addis Ababa). Ice is used on neither fishing boats nor 
collector vessels. At landings, fish is traded fresh for rapid consumption or resale. However, at trader collection points, freezers are used and the frozen fish is then sent to Addis Ababa and local urban markets (even those situated on lakes). Thus, the fish products on sale in Addis Ababa (and in urban centers near the production areas) are frozen-and very often filleted (or more accurately, the fish is semi-frozen on arrival in Addis Ababa, following transport in normal non-insulated trucks). There is also a tradition of dried fish consumption (particularly catfish) in some parts of Ethiopia, notably Tigray and Gambella (Hussen Abegaz et al., 2010).

\subsection{Fish Demand and supply pattern in Ethiopia}

Fish consumption presents a complex pattern, ranging greatly between countries and within different areas in the same country or region. Fish consumption varies greatly depending on the quantities of fish supply available for consumption produced from capture and/or cultured or imported. Ethiopians do not consume large quantities of fish, although there is no religious prohibition for the Christian and Muslim populations. Rather, this is a country with a strong tradition of livestock rearing and meat consumption. The Ethiopian Orthodox Church observes several fasting periods as well as fasting days every week, when meat is not consumed. Most Christians consider fish acceptable during those periods, though some strict followers will not eat any animal products (Brook Lemma, 2008). These factors give rise to some particular characteristics of fish consumption in Ethiopia. Overall, per capita fish consumption is very low. However, consumption is heavily biased towards quite limited geographical areas (production areas and Addis Ababa) and also heavily weighted towards fasting days (Wednesdays and Fridays) and fasting periods (55 days in March/April, 15 days in August, as well as other periods which may be less widely observed). Increasing scarcity (apparently reflecting both rising demand and supply constraints) has resulted in rising real prices for fish, so there is an increasing tendency for fish to be a luxury product consumed by higher income groups. Moreover, according to the study of Gordon et al. (2007), unreliable evidence that higher income groups may represent a significant source of the increase in demand (reflecting wider exposure to different types of food and echoing the nationwide shift in demand towards fish as a healthier source of animal protein), though population increase (particularly in growing Addis Ababa) and a modest general increase in incomes are also factors.

Even though Ethiopia is endowed with large bodies of inland waters and contains edible fish species, the Baro-Akobo basins and its floodplains, the largest flood plains in the country, fishing is mainly artisanal. The major river systems of the basin include: Alwero, Gilo, Baro, Akobo, Baro Kela, Sore, Gabba, Birbir, Ganji, Bonga and Jejebe Rivers. The most commercially important fish species of the river systems are Oreochromis niloticus, Clarias sp., Polypterus bichir, Heterotis niloticus, Gymanrchus niloticus, Malapterurus sp., Lates niloticus, Alestes spps., Hydrocynus spps., Mormyrops spps., Bagrus spps., Barbus spps. and Labeo horei (Abebe Getahun 2003). Major riverine fishing activities are mainly carried out on Baro River around Gambela and Gilo River near Pugnido town in Gambella. The catch estimates from rivers around Gambella are 5000 tons per year whereas the actual fish production is about 12000 tons per year (Ministry of Water Resources, 1996). In comparison to the lower catchments, there is little fishing in the upper catchments of Baro River. Fishing occurs on the Baro, Sore, Waber, Yabi, Didu, and Uka rivers, but this is purely on a subsistence basis using traditional gears. Generally, fishing in the region is mainly on a subsistence basis and used for family consumption while a small amount is sold at a local market to get extra cash income. Most of the population that lives close to water bodies meets more of their animal protein requirements through fish consumption. Fishery is practiced in a traditional technique and tools as past time activity.

llu Abba Bora zone is gifted with inland water bodies which are rich in faunal diversity such as fishes and others. Recent study by Simagegnew Melaku (unpublished data) identified nine fish species from rivers Sor and Gabba only which are economically important. Riverine Fishery, fishing activity and marketing systems of the Baro- Akobo Basins especially in the Gambella Regional state was roughly assessed by Hussen Abegaz et al. (2010) and other NGOs. However, the fishing activity, fish production and demand outlook in the riverine systems of llu Abba Bora zone such as Saki, Sese, Dogi, Ganji, Sor, Gabba, Dabana and Dedesa is not yet studied. Therefore, the study was aimed to generate base-line data on fishing activity, fish marketing systems and demand outlook of llu Abba Bora Zone that would help in the proper and sustainable utilization of the resources.

\section{MATERIALS AND METHODS}

\subsection{Description of the study area}

This study was conducted in llu Abba Bora Zone focusing on some districts with riverine water bodies. Ilu Abba Bora zone is one of the zones of Oromia regional state located in South West of Ethiopia (Figure.1). 


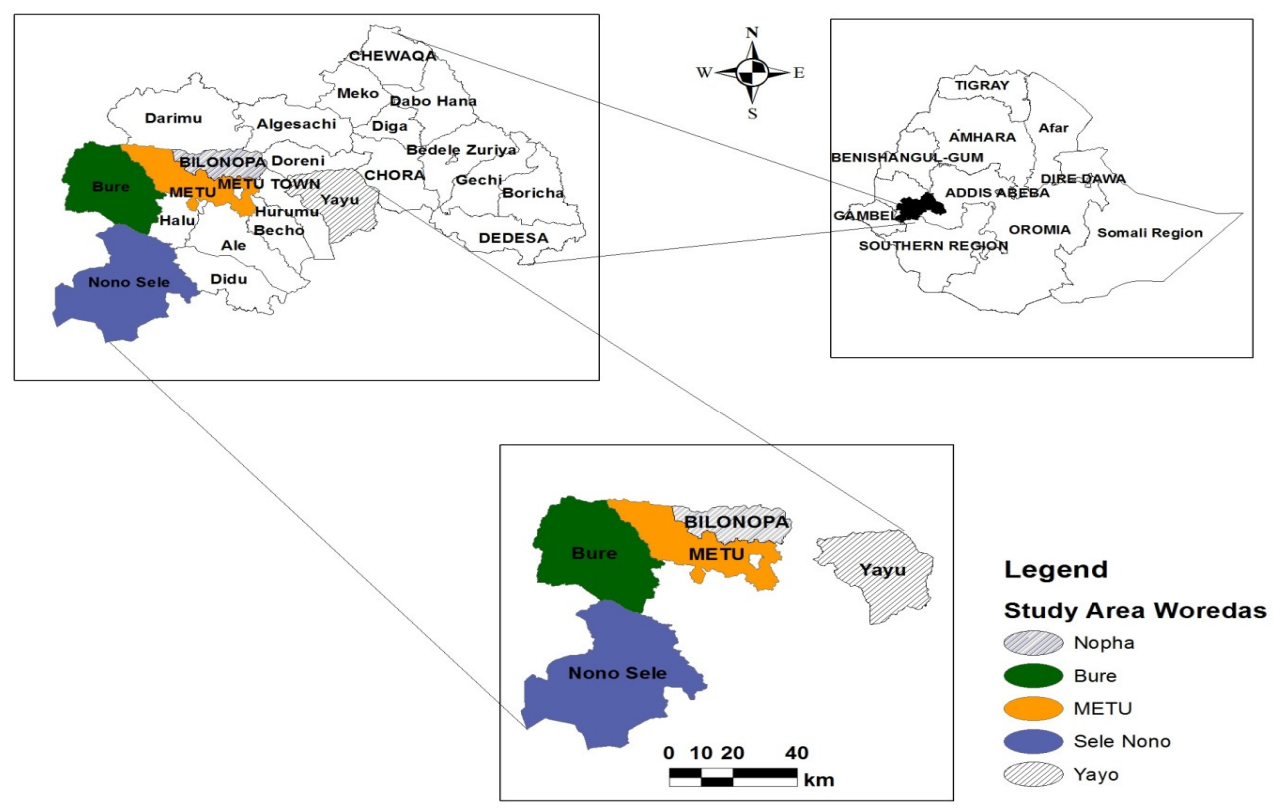

Figure 1. Map of study area and its main rivers

\subsubsection{Land covers}

Ilu Abba Bora zone has a total area of $16,331.56 \mathrm{~km}^{2}$ and the land form is characterized by undulating and dissected plateaus dominantly lying between $1500 \mathrm{~m}$ to 2500 meters above sea level. However, there are narrow strips of lowland less than $1500 \mathrm{~m}$ altitude at the north eastern along Dhedhesa river valley and south western of Baro river valley (Solomon Abebe, 1994).

\subsubsection{Vegetation}

Ilu Abba Bora zone is relatively under good vegetation cover of tropical montane evergreen rainforest on the highlands. The vegetation cover gradually changes to bush shrubs, open deciduous and savanna when one descended to the eastern and western lowlands. The vegetations in the valley bottom wetlands are dominantly sedge (Cyperus latifolius) (Dixon and Wood, 2003). Nearly $30 \%$ of the surface area of llu Abba Bora Zone is under forest cover (mainly natural forest). The forest cover significantly varies between Weredas. Sale Nono (68\%), Yayu Hurumu (55.8\%), Ale Didu (43.9\%), Metu (37\%) and Alge Sachi (33\%) are the five Weredas with large areas of forest cover whereas Bedele Dabo (3.7\%) Darimu (10.7\%) and Dhedhesa (14\%) are Weredas with lower forest cover (Legesse Taffa, 2007).

\subsubsection{Agroecology}

Ilu Abba Bora Zone is one of the zones of Oromia regional states located in the south- western part of Ethiopia. It lies between latitudes $7^{\circ} 05^{\prime}$ to $8^{\circ} 45^{\prime}$ North and longitudes $33^{\circ} 47^{\prime}$ to $36^{\circ} 52^{\prime}$ east (CSA, 2007). It is bordered to the north by East and West Wollega zones, to the south by Kefa Zone, to the east by Jimma Zone and to the west by Gambella Region. The zone shows varied topographic features which influence the vegetation cover, the soil type and the climatic conditions. The altitude of the area ranges between 1500m - 2500 meters above sea level (Dixon, 2003). Due to the altitude and windward location to the moist monsoon winds, Ilu Abba Bora highlands are among the places which receive the highest amount of annual rainfall in Ethiopia (Asmamaw Legesse, 1998). The total annual rainfall of the zone is between $1200-2000 \mathrm{~mm}$ and the mean temperature is $20.5^{\circ} \mathrm{C}$. The rainfall has unimodal pattern where about $85 \%$ occurs between May and October. June, July, August and September are the peak rainy months while December, January and February are the driest months. The warmest months are February, March and April. Temperature decline during the peak rainy months due to the effect of cloud cover (Asmamaw Legesse, 2007).

\subsubsection{Agriculture and economy}

The dominant economic activity in llu Abba Bora is farming which includes both crop production and livestock keeping. Maize (Zea Maizes), sorghum (Sorghum bicolors) and teff (Eragrostis teff) respectively are the staple food crops while coffee is the major cash crop. In general speaking, llu Abba Bora has no experience of serious food deficit (Asmamaw Legesse, 2007). Livestock, primarily cattle, are important in the rural economy, although the ratio of cattle to people is less than in most parts of the highlands due to the lack of grazing. Ox-drawn plough cultivation is practiced although only half the rural households own oxen. Grazing tends not to be restricted to certain areas of farmland except during the growing season. In many areas, the practice of pen rotation is used to ensure an 
even application of animal manure into the soil enhancing its productivity. Domestic animals such as sheep and goats are also reared primarily for their meat which fetches a high market price during religious festivals (Afework and Dixton, 2000).

\subsubsection{Demographic characteristics}

According to the Central Statistical Authority (2007) house and population census, the population of llu Abba Bora for the year 2007 is 1,271,609 (90.21\% rural and $9.79 \%$ urban). This population is with an average crude density of 69 persons $/ \mathrm{km}^{2}$ and agricultural density (the ratio total rural population to cultivated land) of 230 person/ $\mathrm{km}^{2}$. The crude density ranges from 127 persons $/ \mathrm{km}^{2}$ in Chora Wereda to 13 persons $/ \mathrm{km}^{2}$ in Sale Nono Wereda. Agricultural density is the highest for Sale Nono Wereda because of the largest portion (68\%) of the total area occupied by forest (DFED, 2001). The area has several pull factors (fertile lands, mild climate, and suitable environment for coffee production, forest and water resources) that attract inward migrations (Solomon Abebe, 1994). A significant number of people migrated into this area over the past centuries and affected the demography of the area (Alemneh, 1990 as cited in Asmamaw Legesse, 2007).

\subsection{Study Design}

The methodologies employed were review of different reports, field assessment, consultation and exchange of information, ideas and opinions with relevant organizations and individuals in some districts of $\mathrm{ll}$ Abba Bora Zone. The Fishery activity, fish market and demand were studied with full participation of all stakeholders including the local people, districts and zonal livestock and fishery experts. The fishermen, consumers, and households were also interviewed using structured and semi-structured questionnaires. Observation was also made at different fishing sites along the rivers of Sor, Gabba and their tributaries.

\subsection{Sampling Techniques and data collection}

Purposive sampling technique was employed to select the districts based on fishing activities along the rivers. Accordingly, five districts (Mettu, Yayo, Bilo Nopa, Bure and Sale Nono) were selected. From each district, fishermen and households along and nearer to riverine water bodies were selected purposively. Data were collected directly via observation, interview, and making focus group discussion with some selected fishermen and different experts at districts and the zonal level.

\subsection{Data analysis}

Data collected through questionnaire, interview and field observations were analyzed quantitatively and qualitatively using Microsoft excel sheet. Fishing activity, fish species preference among different districts and demand and supply relationship were also described using percentile.

\section{RESULTS AND DISCUSSION}

\subsection{Water and Fish resources of llu Abba Bora}

\subsubsection{Water resources}

Ilu Abba Bora highlands are sources of many rivers due to physiographic and climatic conditions. The highlands fall within two sub-drainage basins that flow to the Mediterranean Sea through Nile River. The eastern part is drained by Dhedhesa and Dabana rivers that flow to Blue Nile while the western part is drained by the upper tributaries of Sobat that join White Nile such as Sor, Gabba, Dogi, Saki, Ganji, Kabar, Gumero, Baro kela, Siba, Yea Bure, Adami, Qonor and many others (Asmamaw, 1998). llu Aba Bora zone is also highly endowed with many permanent and seasonal wetlands used for different socioeconomic benefits such as cattle grazing, vegetable and crop production during dry season.

\subsubsection{Fish species diversity}

The fish species diversity and composition also varies within the Ethiopian geographical areas. The water resource of the llu Abba Bora zone is part of the White Nile system. The White Nile system within the territory of Ethiopia accommodates the most diverse fish fauna (Golubtsov et al., 1995). The zone has less fish diversity but with high fish potential. Golubstov and Darkov (2008) reported only six fish species from Gabba River at the bridge along the road Mettu to Gimbi and their tributaries while Simagegnew (2013) reported nine fish species represented in four families and seven genera from Gabba and Sor Rivers.

\subsection{Commercially important fish species}

Regarding the commercially important fish species, Abebe et al. (2008) reported that the major commercially important fish species of Ethiopia include Oreochromis niloticus, Labeobarbus spp., Lates niloticus, Clarias gariepinus, Bagrus docmak, and Cyprinus carpio (introduced). In the riverine water bodies of Baro Akobo basin, Hussen Abagaz et al (2010) identified 20 commercially important fish species. Thus majorities of commercially important fish species of llu Abba Bora zone are more than four genera and 9 species (Table 1 and Figure 2). 
Table 1. Commercially important fish species from some llu Abba Bora rivers (Sor and Gabba)

\begin{tabular}{lll}
\hline Genera & Scientific name & Local Name \\
\hline \hline Mormyrus & Mormyrus hasselquistii & Gillo Aredamale \\
Garra & Garra spp. & - \\
Labeo & Labeo cylindricus & - \\
Labeo & Labeo forskalii & Genbareteftafa \\
Raiamas & Raiamas senegalensis & - \\
Labeobarbus & Labeobarbus intermedius & Daltu adi/Faranji \\
Labeobarbus & Labeobarbus nedgia & Daltu adi \\
Bagrus & Bagrus docmak & Farkus/Gilo Abareda \\
Oreochromis & Oreochromis niloticus & Orome/Batte \\
Heterobranchus & Heterobranchus bidorsalis & Anbaza \\
\hline
\end{tabular}

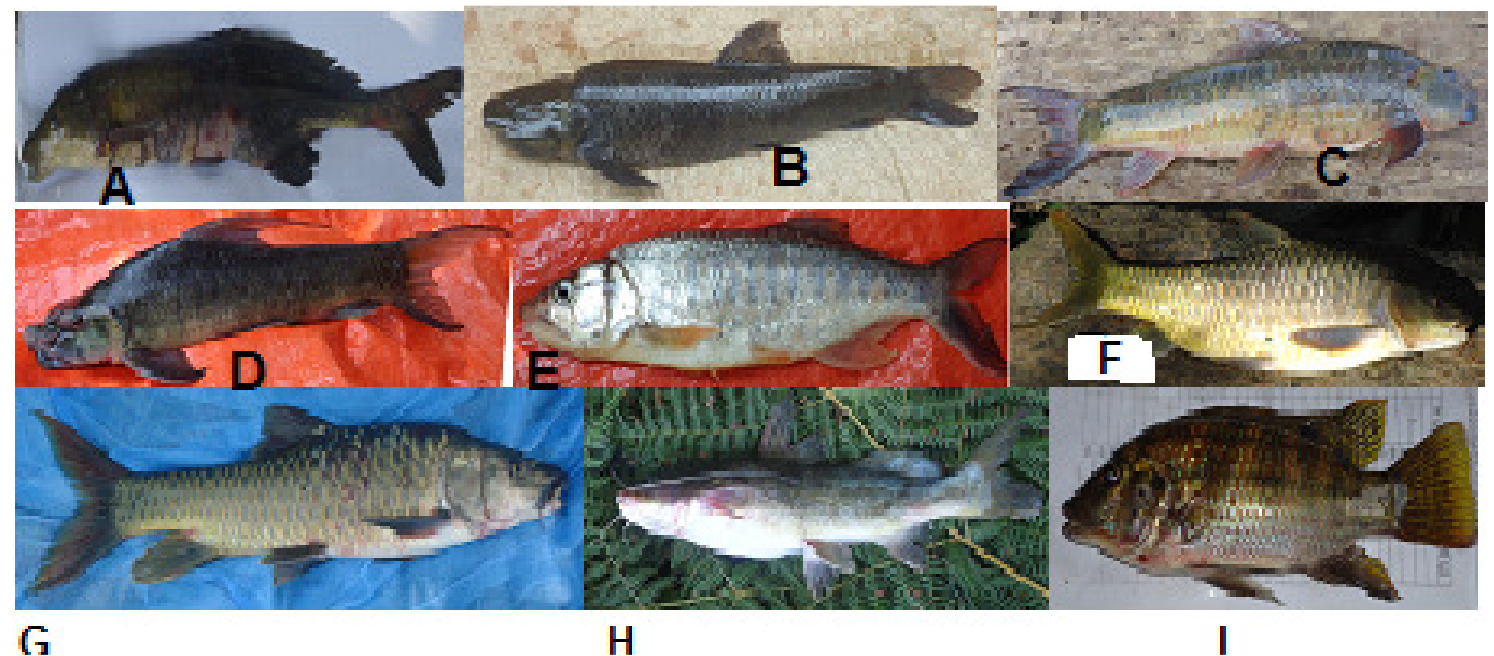

Figure 2. Commercially important fish species from some llu Abba Bora rivers (Sor and Gabba); Mormyrus hasselquistii(A), Garra sp.(B), Labeo cylindricus(C), Labeo forskalii(D), Raiamas senegalensis(E), Labeobarbus intermedius(F), Labeobarbus nedgia(G), Bagrus docmak(H), Oreochromis niloticus(I)

\subsection{Fishing Activity and Fishing gears}

Fishing activity is common in most water bodies of Ethiopia with different fishing gears. For instance, in the rift valley lakes of Ethiopia such as Lake Awasa, Langano, Chamo, and Abaya fishing activity is carried out with gears ranging from hand hooks to motorized fisheries association. In Baro Akobo basins especially in the water bodies (rivers, lakes and floodplains) of Gambella region, fishery support the livelihood of many people and fishermen use more than 15 types of gears which are diversified in season, method of fishing and materials they are made of (Husssen Abagaz et al., 2010). Fishing occurs in different rivers of Ilu Abba Bora zone such as Sor, Gabba, Dabana, Didhessa, Ganji,
Baro kela, Kabar, Gumero and other rivers. The fishing activities on these rivers are on subsistence basis by part-time fishermen for family consumption and sale on small scale during dry season. Fishing is commonly carried out mostly at the end of rainy season (starting from October) and continues to the beginning of the rainy season (April). The fishing gears commonly used are hooks of different sizes (Fig 3A); traps (fish basket) (Fig. 4) locally made and rarely gillnet (Figure 3B). Birbira (Milletia ferruginea) is also used by fishermen in Sale Nono district on river Ganji. The rivers of llu Abba Bora zone such as Gabba, Dogi, Ganji, Gumaro and others are not well accessible due to the dense forest covering the river banks. 


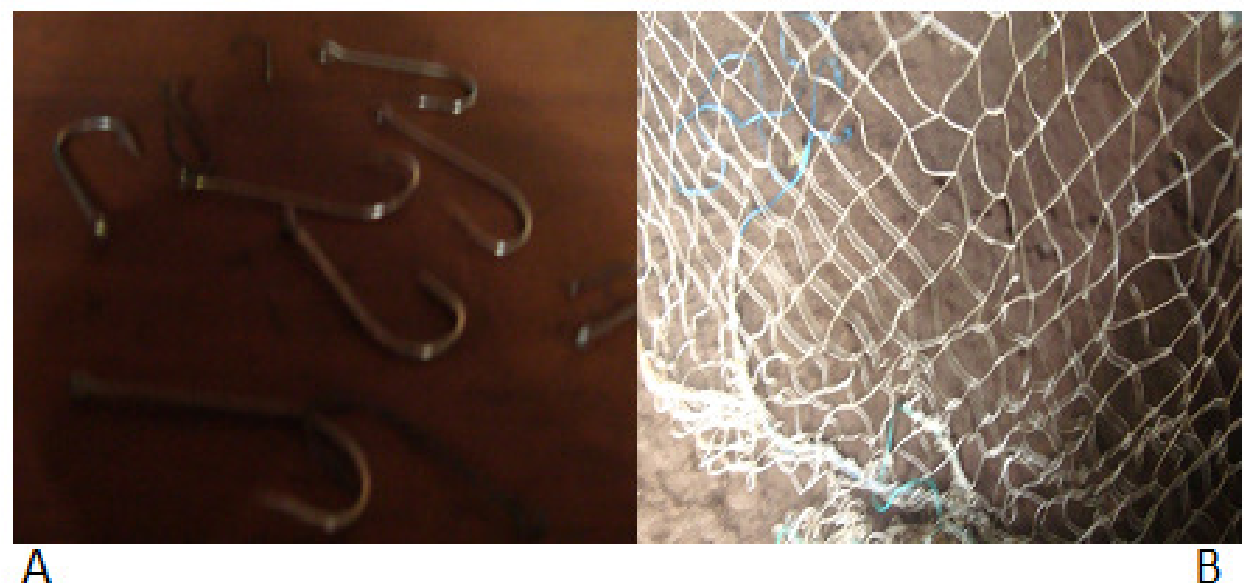

Figure 3. Fishing gears; (A): hooks of different sizes; (B): gill net (10 cm mesh size) used by few fishermen in Gabba River in Yayo area and different rivers of llu Abba Bora, Southwest Ethiopia

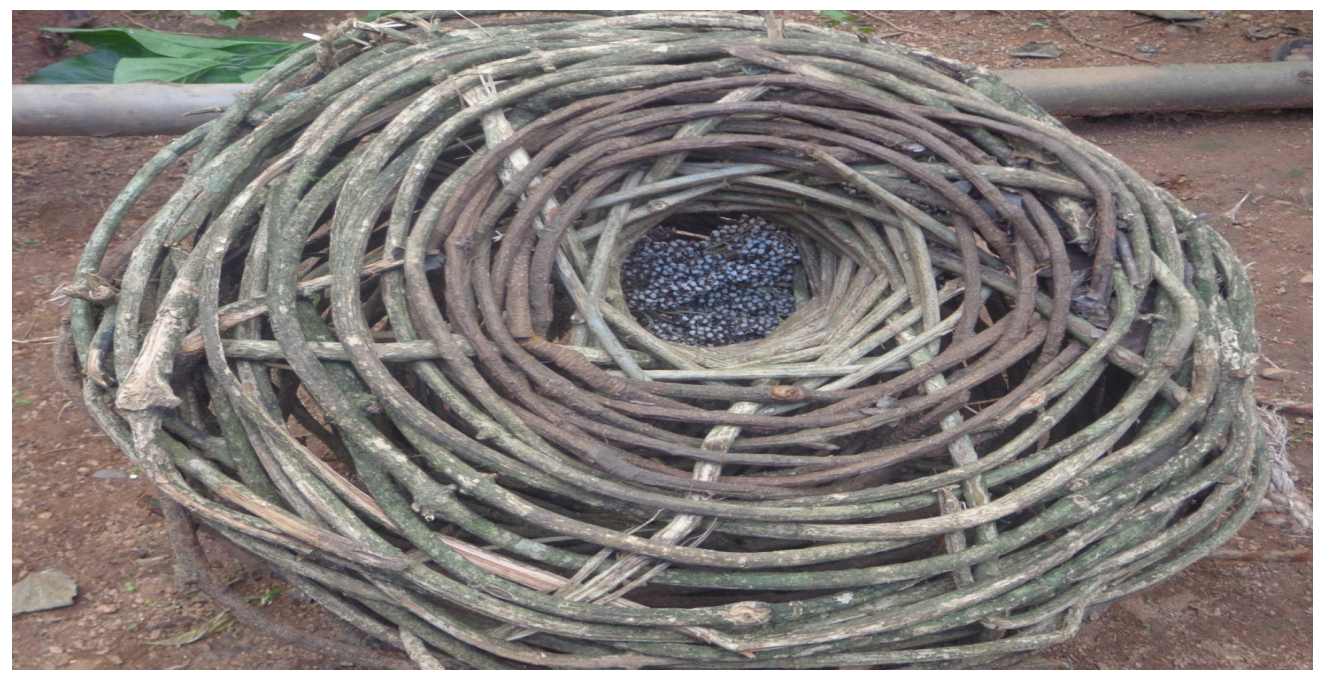

Figure 4. Fishing gear (Trap or fish basket locally called Gubo) with edible crop to lure fishes

\subsection{Awareness and willingness to engage in fishing activity}

The local people living near water bodies such as lakes and rivers in other parts of Ethiopia have awareness about the economic and nutritional value of fishes. The local people living near the different rivers of llu Abba Bora and few individuals in the town of Mettu, Yayo, Nopha and Sale Nono are involved in fishing activity. Fishes caught by the people are mainly used for house hold consumption and for sale on individual basis during dry seasons commonly on fasting periods. In other parts of Ethiopia, there are organized fishery cooperatives on lakes and rivers. For instance on Lake Tana and rift valley lakes, there are fishery cooperatives working on fish production and marketing system (Gordon et al., 2007). There are also fishing cooperatives in the Baro Akobo basins in the Gambella regions on Baro, Gillo,
Alwero and other lakes and rivers in the region (Hussen Abagaz et al., 2010). In the different rivers of llu Abba Bora, there are no organized fishery activities. However, there are initiatives of fishery cooperatives organized for pond fish farming in Yayo, Darimu and Didu districts by livestock experts (Personal communication with zonal expert). As one part of agricultural activities, people living near the different rivers of the zone do not have enough awareness to be engaged in the capture fishery and fish farming despite the presence of abundant seasonal and permanent water bodies including wetlands in the zone.

\subsection{Fish marketing and distribution}

\subsubsection{Fish demand and supply}


The fish demand in the Mettu town is far higher than the available fishes in the town. This is most probably due to the people around Mettu town who have awareness about nutritional value of fish due to their placement of the town near Sor river. The increment of urban people and the urbanization also increased the demand for fish (BoFED, 2007). Contrastingly, in towns like Yayo and Nopha, the demand for fish consumption is low. This is because the people living around these towns do not have awareness about the nutritional value of the fish. Assefa Mitike Janko (2014) also reported that domestic fish market is low outside Addis Ababa, Bahirdar and towns in the main rift valley due to the absence of integration of fish in the daily diet of most of the population, limited supply and religious influence.

\subsubsection{Tradition of fish consumption and fish species preference}

Fish is an important source of food and income to many people in the developed world. In Africa, some 5 percent of the population, about 35 million people, depend wholly or partly on the fisheries sector for their livelihood. Various traditional methods are employed to preserve and process fish for consumption and storage. These include smoking, salting, drying, boiling, marinating and different combination of these. In Ethiopia, since early days fish has been consumed fresh, and it is still the wish of many people to eat fish fresh as soon as possible after catching (Abera Degebasa, 2010). The variety of fish products for consumption is different from district to district in the zone. Accordingly, $73 \%$ of respondents in Mettu town responded as whole fresh fish was preferred fish products while about $26.5 \%$ respondents responded as gutted fish but fillet and dried fish were not accustomed around Mettu. In the case of Yayo, all of the respondents (100\%) responded that gutted fish were marketed by fishermen in the district (Fig.5) and similarly in Sale nono district. Most of the respondents do not have storage facilities but they have tried to improve the shelf life of the fish by processing. Some of the producers gutted (removing the stomach content and other internal organs) immediately after caught. The result of this study agrees with the study done by Hussien Abegaz et al. (2010) in which they use gutted fish as tradition of fish consumption in Gambella region but does not agree with the findings of Gordon et al. (2007) in which outside of the production areas, much of the local trade prefer fresh whole fish, there is also a relatively strong preference for fillets and most frozen fish is traded as fillets. Fish species preference was dependent on the availability of species at different water bodies, but as a whole, Tilapia, Cat fish, Carp and Barbus were the most preferred fish species successively in the study area.

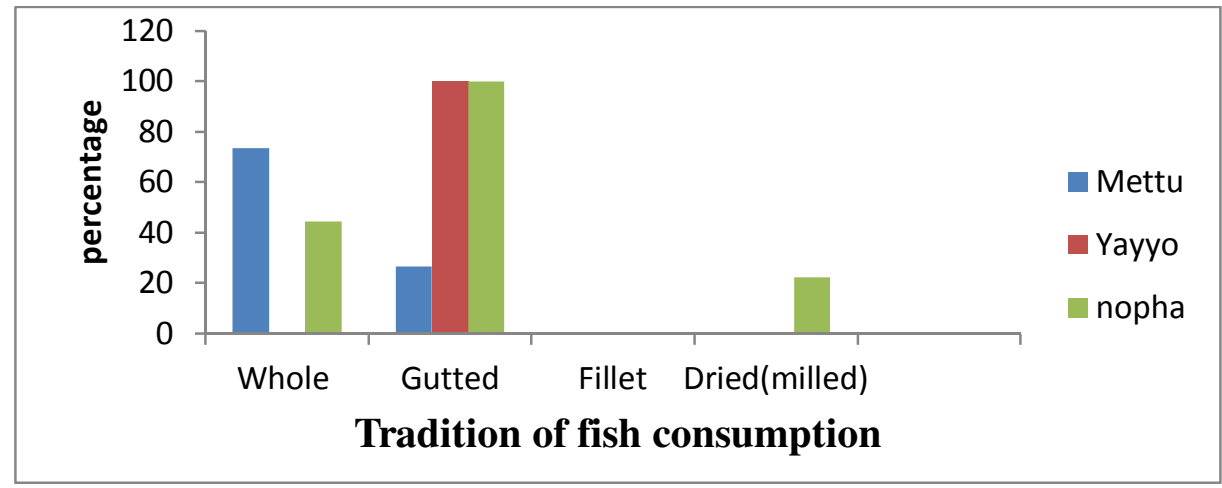

Figure 5. The tradition of fish consumption in some districts of llu Aba Bora Zone

\subsection{Fish production constraints}

The fishermen were interviewed about the existing production constraints and they generally responded and ranked them according to their importance: Accordingly, demand for fish was ranked as the first most important constraint while lack of awareness was ranked as the least observed constraint in Mettu town (Fig.6). But the rank of constraints in Yayo and Nopha districts were different from Mettu town i.e. in both districts, the respondents ranked lack of facility as the first most important constraint and demand for fish as the least observed constraint (Fig. 7). This research is in line with the finding of Hussien Abegaz et al. (2010) in which lack of transportation facilities, proper fishing gears; they all use hook for fishing, poor post harvest handling, low price of fish as a result of low bargaining power of producers, lack of proper fish processing and storage facilities, poor extension service, lack of awareness, poor culture of eating fish, lack of permanent fish market places (shops) are the main fish production constraints in Afar region. The result of this study also in agreement with the finding of Gordon et al. (2007) in which physical access to landing points, collector boat collection points, and road-side traders, loss of quality because of limited options for conservation and time/distance from trading points are major marketing constraints faced by the fishermen. 


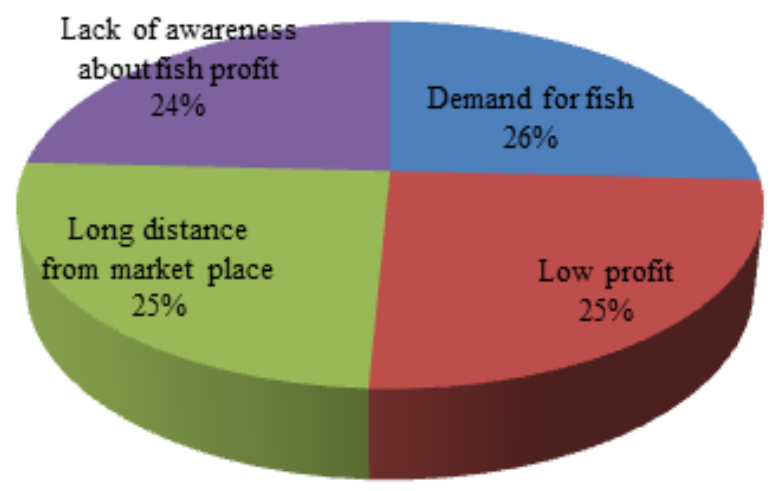

Figure 6. The rank of fish production constraint in Mettu town

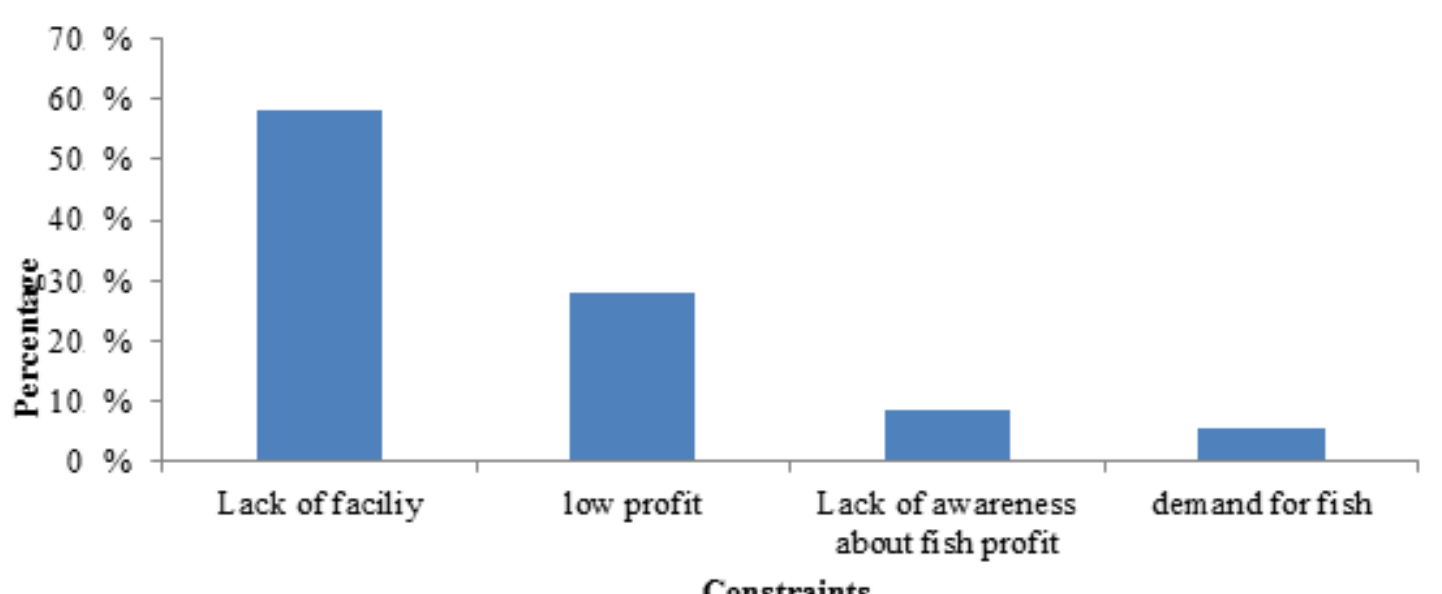

Figure 7. The rank of fish production constraint in Yayo and Nopha districts

\section{CONCLUSIONS}

Fishing occurs in different rivers of llu Abba Bora zone such as Sor, Gabba, Dabana, Didhessa, Ganji, Baro kela, Kabar, Gumero and other rivers. The fishing activities of these rivers are on subsistence basis by part-time fishermen for family consumption and sale on small scale during dry season. Fishing is commonly carried out mostly at the end of rainy season (starting from October) and continues to the beginning of rainy season (April). Hooks of different sizes, traps (fish basket) locally made and rarely gillnet are the fishing gears commonly used in the area. Birbira (Milletia ferruginea) is also used by fishermen in Sale Nono district. Demand for fish, lack of awareness, lack of facility, low profit, and distance from market place are the main fish production constraints in the area though the severity of the constraints varies from one district to the other. The fish demand and supply vary from one district to the other within Ilu Aba Bora zone. Fresh whole fish, gutted and dried fish are mostly preferred fish products. Labeobarbus intermediu, Labeobarbus nedgia,
Bagrus docmak and, Oreochromis niloticus are the fish species preferred by consumers in the study area.

\section{COMPETING INTERESTS}

The authors have no competing interests to disclose.

\section{ACKNOWLEDGEMENTS}

The authors thank Mettu University for the research grant. We are also ever grateful and immensely indebted to colleagues for their encouragement and constructive critic of the research paper.

\section{REFERENCES}

Abebe Getahun (2003). The Nile in the Ethiopian Territory: Riverine fish and fisheries. A paper presented at the Food and Water challenge 
international workshop that took place in Addis Ababa, Ethiopia.

Abera Degebassa (2010). Technical and socio-economic characteristics of fishing activities, fish handling and processing in Ethiopia, In: Management of shallow water bodies for improved productivity and peoples' livelihoods in Ethiopia. Editors: Seyoum Mengistu and Brook Lemma, EFASA, Addis Ababa University Printing Press, Addis Ababa.

Asmamaw, Legesse, (1998). Soil degradation and soil management system in and around Chebere wetland, llu Aba Bora, a thesis presented to Addis Ababa University, 119pp.

Brook Lemma (1987). The present status and potentials for future development of inland fisheries in Ethiopia. In: Proceeding of Management of Water and Natural Resource to increase food production in Africa, IAR, pp. 99-108.

Brook Lema (2008). Introduction to Lake Ecology, Aquaculture and Fisheries in Ethiopia, AAU printing press.

Dixon, A. and Wood, A. (2003), Wetland cultivation and hydrological management in Eastern Africa: Community and hydrological needs through sustainable wetland use, Natural Resource Forum 27 (2003): 117-129.

FAO (1995). Code of Conduct for Responsible Fisheries. Rome, FAO.

FAO (1995); Review of the fisheries and Aquaculture sector: Ethiopia .FAO fisheries Circular No. 890, Rome 29pp.

FAO (2002). Environmental News Service; The New Internationalist magazine issue 325, www.newint.org; www.fao.org; www.enn.com

FAO (2010). The State of World Fisheries and Aquaculture 2010. Rome;197p

Gordon A, Sewmehon Demissie Tegegne and Melaku Tadesse (2007). Marketing systems for fish from Lake Tana, Ethiopia: Opportunities for improved marketing and livelihoods. IPMS (Improving Productivity and Market Success) of Ethiopian Farmers Project Working Paper 2. ILRI (International Livestock Research Institute), Nairobi, Kenya. 49 pp.

Hussien Abegaz, Gashaw Tesfaye and Abebe Cheffo (2010). Fishery Development Program: Riverine Fishery Assessment in Gambella Peoples' Regional State.

Livestock Development and Marketing Agency (LDMA) of llu Abba Bora Zone Department of Agriculture. Mettu, Ethiopia (2011). Annual progress report.

Mebrat Alemneh (1993). Overview of the fishery sector in Ethiopia. In Proceedings of the National Seminar on Fisheries Policy and Strategy. Addis Ababa (Ethiopia). Rome, FAO. pp 45-53.

Legessse Taffa (2007). The Dynamics of Wetland Ecosystems: A Case Study on Hydrologic Dynamics of the Wetlands of Ilu Abba Bora Highlands, Southwest Ethiopia, p108.

Semagegnewu Melaku (2013). Diversity, Relative Abundance and Some Biological Aspects of Fishes in Geba and Sor Rivers, Baro-Akobo Basin, Southwest Ethiopia, Jima University MSc. thesis, unpublished.

Shibru Tedla (1973). Freshwater fishes of Ethiopia. Department of Biology, Addis Ababa University, Addis Ababa, Ethiopia, p 101.

Solomon Abebe. (1994). Land use dynamics, soil degradation and potential for sustainable use in mettu Area, llu aba Bora zone Ethiopia, African study series A13, University of Berne, 119pp

World fish center (WFC) (2009). Fish supply and food security in Africa.

Wudneh Tesfaye (1998). Biology and management of fish stocks in Bahir DarGulf, Lake Tana, Ethiopia. Ph.D. Thesis, Department of Fish Culture and Fisheries, Wageningen Agricultural University. Pp 1144 